\title{
SITUACIÓN DE LA AGRICULTURA DE MAYOS Y MESTIZOS DEL NORTE DE SINALOA, MÉXICO
}

\section{SITUATION OF AGRICULTURE OF MAYOS AND MESTIZOS IN NORTHERN SINALOA, MÉXICO}

\author{
Estuardo Lara-Ponce ${ }^{1^{*}}$, J. Luis Valdés-Vega ${ }^{2}$, S. Martín Medina-Torres ${ }^{3}$, Rosa Martínez-Ruíz ${ }^{3}$ \\ ${ }^{1}$ Universidad Autónoma Intercultural de Sinaloa (UAIS). Juárez 39, El Fuerte, Sinaloa. Tel. \\ 01 (698) 892-06-54. 81890. (elara02@hotmail.com). ${ }^{2}$ Universidad de Occidente, Unidad El \\ Fuerte, Sinaloa. 01(668) 816-10-50. 81200. ${ }^{3}$ Consultores Independientes.
}

\section{RESUMEN}

En la localidad de Jahuara II se realizó una investigación mixta, con el objetivo de sistematizar y comparar información ambiental, social, cultural y económica de la agricultura de maíz, que tradicionalmente practican agricultores indígenas mayos y mestizos. La metodología incluyó revisión documental, observación participante, entrevistas y encuestas con un muestreo intencional a 53 ejidatarios entre 49 y 80 ańos. La interpretación de datos ambientales señala que las limitantes para la producción de maíz son la escasa precipitación y las bajas temperaturas. En lo sociocultural, ambos grupos conservan elementos de su identidad asociadas al conocimiento agrícola. Tecnológicamente practican una agricultura comercial y similar en sus componentes; sin embargo, la semilla criolla de maíz es más empleada por los mayos, quienes comparativamente con los mestizos obtuvieron rendimientos ligeramente mayores en riego, como de temporal. En lo económico existe una relación costo/beneficio promedio favorable en ambos grupos de agricultores, aunque los costos de producción por hectárea sembrada son elevados en ambos casos. Los mayos han perdido terrenos de cultivo por razones socioeconómicas, han dejado de sembrar superficies de maíz criollo y han abandonado prácticas tradicionales. La erosión del conocimiento de la agricultura indígena se observa en la posible extinción de la diversidad de los maíces criollos de la región, situación que impacta el patrimonio biocultural de los mayos y mestizos. Es urgente valorar los conocimientos ancestrales del manejo de la agricultura, cuyo potencial genético es reconocido por los centros de investigación agrícola y significan una expectativa favorable de estudio para enfrontar la problemática climática regional.

* Autor responsable * Author for correspondence. Recibido: noviembre, 2015. Aprobado: noviembre, 2016. Publicado como ARTÍCULO en ASyD 14: 577-597. 2017.

\section{Abstract}

A mixed study was carried out in the locality of Jahuara II, with the objective of systematizing and comparing environmental, social, cultural and economic information about maize agriculture, which is practiced traditionally by Mayo and Mestizo indigenous farmers. The methodology included documentary review, participant observation, and interviews and surveys with intentional sampling with 53 ejidatarios of 49 to 80 years old. The interpretation of environmental data suggests that the limitations for maize production are scarce rainfall and low temperatures. In sociocultural terms, both groups conserve elements of their identity associated to agricultural knowledge. Technologically, they practice a commercial agriculture and similar in its components; however, Creole maize seed is used more by Mayos, who compared to the Mestizos obtained slightly higher yields both with irrigation and rainfed. Economically, there is a favorable cost/benefit relationship average in both groups of farmers, although the production costs per hectare sown are high in both cases. The Mayos have lost cultivation lands because of socioeconomic reasons, they have ceased to cultivate surfaces of Creole maize, and have abandoned traditional practices. The erosion of knowledge about indigenous agriculture is observed in the possible extinction of the diversity of Creole maize breeds in the region, situation that impacts the biocultural patrimony of the Mayos and Mestizos. It is urgent to assess the ancestral knowledge of agricultural management, whose genetic potential is recognized by the agricultural research centers and which mean a favorable expectation of study to face the regional climate problem.

Key words: local knowledge, Creole maize breeds, Mayos of Sinaloa, agricultural technology. 
Palabras clave: conocimiento local, maíces criollos, mayos de Sinaloa, tecnología agrícola.

\section{INTRODUCCIÓN}

$\mathrm{E}$ l cultivo de maíz sigue siendo uno de los alimentos básicos para los habitantes de México. Es una de las principales especies que forman parte del complejo sistema tradicional de la milpa que ha sido manejado ancestralmente por los pueblos indígenas y campesinos de Mesoamérica, y del que existe evidencia histórica y registro de la trascendencia sociocultural, económica y ambiental (Goodman and Galinat, 1988; Brush and Perales, 2007; Schwartz and Corzo, 2015, entre otros). Este agroecosistema tradicional también se encuentra estrechamente relacionado con la diversidad biocultural de los sistemas agroforestales que se han desarrollado en distintos contextos culturales y ecológicos del área Mesoaméricana donde coexisten formas de apropiación y aprovechamiento de las especies de cultivo que crecen en la milpa y que han servido de alimentación, además de otros múltiples propósitos de las familias rurales en el transcurso del tiempo (Aguilar et al., 2003; Lara et al., 2012; Moreno-Calles et al., 2013; Fernández et al., 2013).

La economía agrícola que sustenta a las localidades campesinas e indígenas de México agrupa diversas formas de apropiación y valoración de la naturaleza. De acuerdo con Rentería y Mora (2013) esta economía indígena ha tenido al menos dos fases históricas en el noroeste de México, un periodo formativo que consistió en el establecimiento de distintas sociedades de grupos de cazadores, recolectores y pescadores que influyeron en la instauración de los primeros territorios en la región. Es el caso de los antiguos indígenas mayos, quienes fueron grupos hablantes de cahíta del norte de Sinaloa, y parecidos en costumbres, subsistencia, casas, armas y danzas (Carpenter, 2007, citando a Ribas 1944). Según cálculos en la época precolombina existió una población de 30000 personas que vivieron en varias rancherías distribuidas en ambas márgenes del río mayo del que tomaron el nombre.

Un segundo periodo ocurrió con el desarrollo de la agricultura de temporal de los habitantes de la planicie costera y las tierras altas, quienes dependieron de la creciente de los ríos más importantes del área,

\section{INTRODUCTION}

$\mathrm{M}$ aize cultivation continues to be one of the basic foods for inhabitants of México. It is one of the main species that make up the complex traditional system of the milpa that has been managed ancestrally by the indigenous and peasant peoples of Mesoamerica, and about which there is historical evidence and records the sociocultural, economic and environmental transcendence (Goodman and Galinat, 1988; Brush and Perales, 2007; Schwartz and Corzo, 2015, among others). This traditional agroecosystem is also closely linked to the biocultural diversity of agroforestry systems that have developed under different cultural and ecological contexts of the Mesoamerican area where forms of appropriation and exploitation of cultivation species that grow in the milpa coexist, and which have served as food in addition to multiple other purposes for the rural families throughout time (Aguilar et al., 2003; Lara et al., 2012; Moreno-Calles et al., 2013; Fernández et al., 2013).

The agricultural economy that sustains the peasant and indigenous localities of México groups diverse forms of appropriation and valuation of nature. According to Rentería and More (2013), this indigenous economy has had at least two historical phases in northwestern México, with a formative period that consisted in the establishment of different societies of groups of hunters, gatherers and fishermen that influenced the establishment of the first territories in the region. Such is the case of the ancient Mayo indigenous peoples, who were groups that spoke Cahíta in northern Sinaloa, and similar in customs, subsistence, homes, arms and dances (Carpenter, 2007, citing Ribas 1944). According to calculations, in Pre-Hispanic times there was a population of 30000 people who lived in several rancherias distributed in both banks of the Mayo River from which they take the name.

A second period took place with the development of rainfed agriculture of the inhabitants in the coastal flatland and the highlands, who depended on the swelling of the most important rivers in the area, situation that generated processes of sedentarization and stable population settlements known as systems of rancherias or temporary settlements that were occupied in different times of the year, such as summer or winter. The control of important 
situación que generó procesos de sedentarización $\mathrm{y}$ asentamientos poblacionales estables conocidos como sistema de rancherías o poblados temporales que eran ocupadas en distintas épocas del año, como verano o invierno. El control de los ríos importantes de la región fue vital en el desarrollo de la agricultura; la consolidación de grupos sociales y, por ende, el establecimiento de núcleos poblacionales sin abandonar el sistema de rancherías (Rentería y Mora, 2013). Aunque algunos grupos de la planicie eran agricultores de medio tiempo o explotaban extensamente los recursos marinos; los integrantes de estas sociedades agrícolas también realizaban actividades de caza, pesca y recolección. En la lista de los recursos naturales utilizados por los antiguos mayos figuran diversas especies silvestres. El aprovechamiento de la fauna incluía animales domésticos, especies silvestres que proporcionaban cuero y alimento, complementado con diversos peces y mariscos (Carpenter, 2007; Rentería y Mora, 2013).

El ancestral aprovechamiento múltiple de los recursos naturales por las poblaciones de indígenas mayos es un interesante caudal de conocimientos etnobotánicos del que se ha documentado recientemente (Yetman and Van Devender, 2002), y que ofrecieron estrategias de uso de la flora para resolver problemas de adaptación al clima, como la búsqueda de protección por los habitantes de la radiación solar durante el día y las bajas temperaturas en la noche, propias de las zonas áridas y semiáridas, lo que permitió la supervivencia de los pobladores en estas áreas de condiciones ambientales difíciles. En cuanto al abastecimiento de agua, estas culturas del desierto desarrollaron técnicas para almacenar y manipular el recurso hídrico (Casas et al., 2010).

Los mayos contemporáneos habitan el norte de Sinaloa y sur de Sonora; presentan una dinámica sociointercultural propia de un territorio histórico que han habitado por generaciones, el cual según Sandoval-Forero y Meza-Hernández (2013) adquiere el significado de "etnorregión yoreme mayo", cuyas características son el asentamiento ancestral de grupos emparentados con los mayos. La existencia de grupos domésticos y comunidades dispersas, las relaciones asimétricas interculturales, las relaciones económicas, las dinámicas lingüísticas y la diversidad de festividades correspondientes al calendario anual, y la presencia de 19 centros ceremoniales, cuya importancia radica en su antigüedad; esta condición les rivers in the region was vital in the development of agriculture; the consolidation of social groups, and therefore, the establishment of population centers without abandoning the system of rancherias (Rentería and Mora, 2013). Although some groups on the flatland were half-time farmers or exploited extensively marine resources, the members of these agricultural societies also performed hunting, fishing and gathering activities. In the list of natural resources used by the ancient Mayos there are various wild species. The exploitation of fauna included domestic animals, wild species that provided leather and food, complemented with diverse fish and shellfish (Carpenter, 2007; Rentería and Mora, 2013).

The ancestral multiple exploitation of natural resources by Mayo indigenous populations is an interesting source of ethnobotanical knowledge which has been documented recently (Yetman and Van Devender, 2002), and which offered strategies for the use of flora to solve problems of adaptation to climate, such as the search for protection from solar radiation during the day by inhabitants, and from low temperatures during the night, characteristic of arid and semiarid zones, allowing the survival of inhabitants in these areas of difficult environmental conditions. In terms of water supply, these cultures from the desert developed techniques to store and manipulate the water resource (Casas et al., 2010).

The contemporary Mayos reside in northern Sinaloa and southern Sonora; they present a sociointercultural dynamic characteristic of a historical territory that they have inhabited for generations, which according to Sandoval-Forero and MezaHernández (2013) acquires the meaning of "Yoreme Mayo ethnic region", whose characteristics are the ancestral settlement of groups related to the Mayos. The existence of domestic groups and disperse communities, the asymmetrical intercultural relationships, the economic relationships, the linguistic dynamics and the diversity of festivities that correspond to the annual calendar, and the presence of 19 ceremonial centers whose importance lies in their age; this condition has imposed on them the epithet of "old peoples", identified by being chiefly those that follow the course of the Fuerte River (López, 2007). However, a clear definition of the region of the Mayos does not yet exist; its real configuration is still under discussion by researchers, the actual territorial dispersion of the inhabitants 
ha impuesto el apelativo de "pueblos viejos", identificados por ser mayoritariamente los que siguen el curso del río Fuerte (López, 2007). Sin embargo, una definición clara de región de los mayos no existe aún; sigue en discusión por los estudiosos su configuración real, la sola dispersión territorial de los pobladores que asumen esta identidad, es un rasgo común. Considerando esta perspectiva geográfica regional, el pueblo mayo actualmente cuenta con una población estimada en 32 mil habitantes; de esta cantidad, poco más de 11000 pobladores de tres años y más habla lengua mayo (INEGI, 2010).

Los mayos en sus comunidades participan en actividades como la agricultura y tienen formas de tenencia de la tierra en propiedades particulares, ejidales y comunales; se estima que poseen 23365 hectáreas de tierra agrícola ubicadas en zonas de temporal. Particularmente los mayos de Sinaloa tienen como actividades económicas a la agricultura con modalidades de rentismo y migración a campos agrícolas de Sinaloa y Sonora, la práctica de la ganadería extensiva para el autoconsumo y para las fiestas tradicionales, así como la recolección de productos silvestres y el aprovechamiento de la fauna silvestre (Cortés-Gregorio et al., 2013). La pesca ribereńa también es practicada por los pobladores y provee proteína animal primordial para la subsistencia de los mayos. Los trabajos extraparcela involucran a personas que se desempeñan como jornaleros agrícolas, maquiladores, empleados de servicios u obreros, y en la manufactura de artesanías como máscaras de pascola, muñecos danzantes, venados, fariseos, canastas y cobijas (Rentería y Mora, 2013).

Actualmente el noroeste de México es una región que cuenta con las condiciones ambientales y fértiles valles agrícolas, donde el cultivo de maíz arroja buenos rendimientos, fruto del paquete tecnológico de alto rendimiento diseńado para esta agricultura moderna de fines comerciales, aunque no es menor la trascendencia y el potencial de rendimiento del maíz mejorado impulsado por las empresas productoras de semillas, las instituciones de investigación y los agricultores con recursos económicos. Desde otro ángulo, existen pocos estudios que den cuenta de la importancia y situación prevaleciente de la agricultura tradicional del maíz criollo en las áreas de riego, temporal y serranas donde habitan comunidades mestizas e indígenas, quienes son descendientes de los diferentes grupos that assume this identity is a common feature. Considering this regional geographic perspective, the Mayo people currently have a population estimated at 32 thousand inhabitants; of this number, slightly over 11000 inhabitants of three years or more speak the Mayo language (INEGI, 2010).

The Mayos in their communities participate in activities such as agriculture and have land ownership forms in private, ejido and communal properties; it is estimated that they have 23365 hectares of agricultural land located in rainfed zones. Particularly the Mayos in Sinaloa have as economic activities agriculture with modalities of renting and migration to agricultural fields in Sinaloa and Sonora, the practice of extensive livestock production for autoconsumption and for traditional festivities, as well as the gathering of wild products and the exploitation of wild fauna (Cortés-Gregorio et al., 2013). Riverside fishing is also practiced by the inhabitants and provides primordial animal protein for the subsistence of the Mayos. Tasks outside the plot involve people who act as agricultural day laborers, assembly plant workers, service workers or laborers, and who work in the manufacture of handcrafts like pascola masks, danzante figures, deer, fariseos, baskets and blankets (Rentería and Mora, 2013).

Today, northwestern México is a region that has the environmental conditions and fertile agricultural valleys where maize crops have good yield, result of the high-yield technological package for this modern agriculture of commercial aims, although transcendence and potential for improved maize yield promoted by seed-producing companies, research institutions and farmers with economic resources is not less important. From a different angle, there are few studies that reflect the importance and prevalent situation of traditional Creole maize agriculture in the irrigation, rainfed and mountain areas where mestizo and indigenous communities reside, who are descendants from the different cultural groups that inhabited the different ecosystems of the northwestern region of México. Based on the previous background, this study proposed the question about the situation that prevails in the agricultural practice of the Mayos, particularly if there are elements managed according to the ancestral milpa practiced by indigenous people. The objective consisted in systematizing and comparing environmental, social, cultural and economic information about maize 
culturales que habitaron los diferentes ecosistemas de la región noroeste de México. Con base en los antecedentes anteriores, la presente investigación planteó la interrogante sobre la situación que prevalece en la práctica agricultura de los mayos, particularmente si existen elementos manejados de acuerdo con la ancestral milpa practicada por los pueblos indígenas. El objetivo consistió en sistematizar y comparar información ambiental, social, cultural y económica de la agricultura de maíz que tradicionalmente practican agricultores indígenas mayos y mestizos de una comunidad del municipio de El Fuerte, Sinaloa.

\section{Metodología}

\section{Localización de la comunidad}

La localidad de Jahuara II o Villa Adolfo López Mateos se localiza a $54 \mathrm{~km}$ al norte de la ciudad de Los Mochis en la región Norte del Estado de Sinaloa, México. Al norte colinda con terrenos agrícolas del ejido Los Suárez; al este, con terrenos del ejido Metate; al oeste, con terrenos agrícolas del ejido Jahuara; y al sur, con el Dren Colector Jahuara. La población tiene categoría política de sindicatura y por su tamaño poblacional es la cuarta localidad en importancia en el municipio de El Fuerte. Sus coordenadas geográficas son $26^{\circ} 13^{\prime \prime} 37^{\prime} \mathrm{N}$ y $108^{\circ} 57^{\prime \prime} 19^{\prime} \mathrm{O}$ y se encuentra a una altitud de $30 \mathrm{~m}$. De acuerdo con INEGI (2010), Jahuara II tiene una población total de 5025 habitantes, de los cuales 2532 corresponden a hombres y 2493 a mujeres. La población masculina de tres años y más que habla lengua indígena es de 286 y femenina, 261; hay un total de 1190 personas que forman hogares y donde el jefe del mismo habla lengua indígena. La localidad cuenta con una distribución parcelaria de 1680 hectáreas y un total de 208 ejidatarios.

\section{Trabajo de campo}

La investigación es de tipo mixto e incluyó revisión documental, así como métodos de campo para documentar aspectos ambientales, socioculturales, técnicos, económicos y productivos de la agricultura de los mayos y mestizos de la localidad. Como primera fase se realizó una recopilación bibliográfica referente al grupo étnico mayo y la agricultura que se practica en el valle del Fuerte, en el norte de Sinaloa agriculture that is practiced traditionally by Mayo and Mestizo indigenous farmers in a community of the municipality of El Fuerte, Sinaloa.

\section{Methodology}

\section{Location of the community}

The locality of Jahuara II or Villa Adolfo López Mateos is found $54 \mathrm{~km}$ north of the city of Los Mochis in the northern region of the state of Sinaloa, México. To the north, it neighbors with agricultural lands from the ejido of Los Suárez; to the east, with lands from the ejido Metate; to the west, with agricultural lands of the ejido Jahuara; and to the south, with the Jahuara Collector Drain. The town has a political category of sindicatura and because of its population size is the fourth locality in importance of the municipality of El Fuerte. Its geographic coordinates are $26^{\circ} 13^{\prime \prime} 37^{\prime} \mathrm{N}$ and $108^{\circ} 57^{\prime \prime} 19^{\prime} \mathrm{W}$ and is found at an altitude of $30 \mathrm{~m}$. According to INEGI (2010), Jahuara II has a total population of 5025 inhabitants, of which 2532 are men and 2493 women. The male population of three years or more who speaks indigenous language is 286 , and the feminine 261; there are a total of 1190 people who form households and where the head of the household speaks an indigenous language. The locality has a plot distribution of 1680 hectares and a total of 208 ejidatarios.

\section{Field work}

The research is of a mixed type and included documental review, as well as field methods to document environmental, sociocultural, technical, economic and productive aspects of the Mayo and Mestizo agriculture of the locality. As first phase, a bibliographic collection was carried out which refers to the Mayo ethnic group and the agriculture practiced in the valley of El Fuerte, in the north of Sinaloa (INAGI, 2010). In a second phase carried out in the months of October to December 2013, participant observation was performed in community assemblies and key informants were interviewed whose testimonies served as support for the field research. In a third moment, the method of surveys was applied with farmers, both Mayo and Mestizo ejidatarios in the community. The design 
(INEGI, 2010). En una segunda fase realizada en los meses de octubre a diciembre de 2013 se efectuó observación participante en asambleas comunitarias y entrevistaron a informantes claves cuyos testimonios sirvieron de apoyo a la investigación de campo. En un tercer momento se aplicó el método de encuestas a agricultores tanto ejidatarios mayos como mestizos de la comunidad. Se utilizó el diseño de muestreo aleatorio simple de tipo cualitativo, con una precisión de $10 \%$ y un nivel de confianza de $90 \%$; para ello, el comisario ejidal proporcionó el padrón de agricultores de un universo de 278 ejidatarios, del que se obtuvo una muestra de 53 ejidatarios (32 mayos y 21 mestizos) entre 49 y 80 años de género masculino y femenino. Con la información obtenida de las encuestas se generó una base de datos que se analizó en el programa estadístico IBM SPSS ${ }^{\circledR}$ Statistics 19. Los datos de las variables ambientales, como temperatura y precipitación, se obtuvieron de la estación climatológica de Los Mochis, proporcionada por la Comisión Nacional de Agua. En lo económico, para calcular los costos de producción de maíz se utilizaron los indicadores propuestos por el programa técnico agrícola (BASETEC, 1999). Las otras variables complementarias fueron de aspectos relacionados con la agricultura, lo sociocultural y tecnológico.

\section{Resultados y Discusión}

\section{Aspectos ambientales}

Las condiciones agroecológicas de la localidad de Jahuara II determinan la producción en las parcelas de los agricultores, situación que en general es común en la agricultura. En la percepción de los mayos, los suelos de la localidad presentan condiciones "regulares" para la producción de maíz; para los ejidatarios mestizos los suelos se afectan debido a factores no previsibles causados por el clima. Ambos grupos encuestados consideran que los suelos agrícolas no son limitantes debido a sus condiciones naturales. En general en los valles agrícolas donde habitan mayos y mestizos se reportan suelos fértiles para la siembra de cultivos y aptos para la buena producción, como son los de origen vertisol, regosol y phaeozem (INEGI, 2009).

En relación con el clima del norte de Sinaloa, hay dos elementos importantes que influyen en la producción del maíz, la precipitación y la temperatura. of simple random sampling of qualitative type was used, with an accuracy of $10 \%$ and level of trust of $90 \%$; for this purpose, the ejido commissioner provided the registry of farmers with a universe of 278 ejidatarios, from which a sample of 53 ejidatarios was obtained (32 Mayos and 21 Mestizos), between 49 and 80 years old of masculine and feminine gender. With the information obtained from the surveys, a database was generated that was analyzed with the statistical software IBM SPSS $^{\oplus}$ Statistics 19. The data of environmental variables, such as temperature and precipitation, were obtained from the climate station in Los Mochis, provided by the National Water Commission. Economically, in order to calculate the costs of maize production the indicators proposed by the agricultural technical program were used (BASETEC, 1999). The other complementary variables were of aspects related to agricultural, sociocultural and technological aspects.

\section{Results AND Discussion}

\section{Environmental aspects}

The agroecological conditions of the locality of Jahuara II determine the production in the farmers' plots, situation that in general is common in agriculture. In the perception of the Mayos, the soils of the locality present "regular" conditions for maize production; for the Mestizo ejidatarios, the soils are affected due to unpredictable factors caused by the climate. Both groups surveyed considered that the agricultural soils are not limiting due to their natural conditions. In general in the agricultural valleys where Mayos and Mestizos inhabit, fertile soils are reported for sowing crops which are apt for good production, such as those of vertisol, regosol and phaeozem origin (INEGI, 2009).

In relation to the climate in northern Sinaloa, there are two important elements that influence maize production: precipitation and temperature. In the first case, and according to local climate data, the dates for the rain season begin in the month of July and continue during August until October when it rains around 120 millimeters. This brings with it the supply of dams, such as the Miguel Hidalgo dam and the Josefa Ortiz de Domínguez dam, from which water stored is distributed to the Fuerte River, its branches and irrigation channels. In 
En el primer caso y de acuerdo con datos climáticos locales, las fechas de temporada de lluvia empiezan en el mes de julio y continúan durante agosto hasta octubre donde llueve alrededor de 120 milímetros. Ello trae consigo el abastecimiento de presas, como la Miguel Hidalgo y la Josefa Ortiz de Domínguez, de las que se distribuye el agua almacenada al Río Fuerte, sus ramales y canales de riego. En el segundo caso las temperaturas en los meses citados se tornan extremosas con máximas que superan los $40{ }^{\circ} \mathrm{C}$, mientras que en enero y febrero se presentan las más bajas $\left(<10{ }^{\circ} \mathrm{C}\right)$ (Figura 1). La presencia de los siniestros climatológicos en la región son preocupantes para los ejidatarios mayos y mestizos; de acuerdo con su percepción, la sequía les afecta en sus cultivos de 53.2 a $57.1 \%$; las bajas temperaturas, de 40.6 a $42.9 \%$; y el efecto de la combinación de lluvias y el viento en menor proporción (3.1\%). En ambos grupos la apreciación de falta de lluvias o presencia de sequía influye en la no recarga de las presas y diques, y son condiciones climáticas determinantes en el distrito de riego del Valle del Carrizo. Al retrasarse la fecha de siembra los ejidatarios toman medidas, como

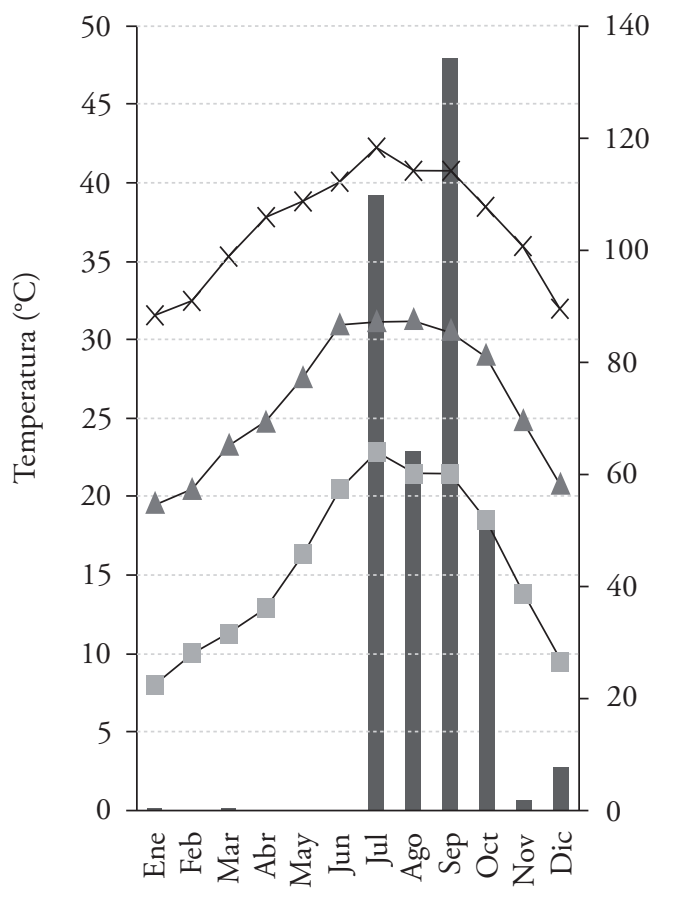

the second case, the temperatures during the months cited become extreme with maximums that exceed $40{ }^{\circ} \mathrm{C}$, while in January and February the lowest are present $\left(<10^{\circ} \mathrm{C}\right)$ (Figure 1). The presence of climate disasters in the region are worrying for the Mayo and Mestizo ejidatarios; according to their perception, drought affects their crops in 53.2 to $57.1 \%$; the low temperatures, in 40.6 to $42.9 \%$; and the effect of the combination of rains and wind in a lower proportion (3.1\%). In both groups the assessment of lack of rains or presence of drought influences the lack of reload of dams and dikes, and are defining climate conditions in the irrigation district of Valle del Carrizo. When the sowing date is delayed, the ejidatarios take steps such as eliminating one irrigation event on the crop although it affects the growth and development of the plant. Instead, the low temperatures cause frosts and damage on maize that are foreseeable; when they are severe it is impossible to recover the state of the plant, particularly when the frosts take place before or during the stage of the ears of corn. The low temperatures in Valle del Carrizo in the last five years have caused losses in agriculture; particularly, in

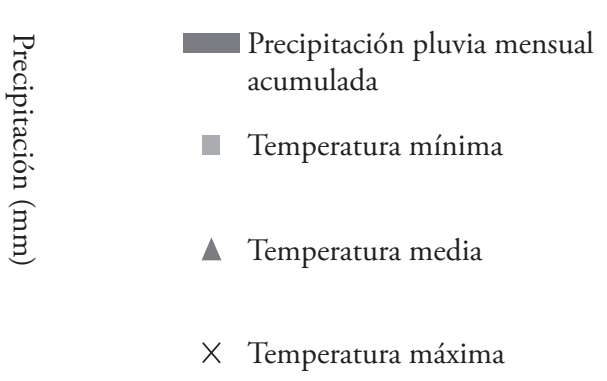

Figura 1. Distribución de la precipitación y las temperaturas promedio durante los ciclos anuales 2013-2014, estación climatológica Los Mochis, Sinaloa.

Figure 1. Distribution of precipitation and average temperatures during the 2013-2014 annual cycles, climatological station in Los Mochis, Sinaloa. 
eliminar un riego al cultivo aunque repercuta en el crecimiento y desarrollo de la planta. Las bajas temperaturas en cambio causan heladas y daños al maíz que son previsibles; cuando son severas es imposible recuperar el estado de la planta, sobre todo cuando las heladas se presentan antes o durante la etapa de elote. Las bajas temperaturas en el Valle del Carrizo en los últimos cinco años han provocado pérdidas en la agricultura; particularmente, en 2013 se presentaron descensos de temperatura que causaron heladas y daños considerables a cultivos como el maíz, frijol y hortalizas ${ }^{1}$.

El impacto de ambas variables climáticas en la agricultura regional es cada vez mayor. Información reciente señala que la tendencia generalizada en el noroeste de México es de un incremento de temperatura y de disminución de la cantidad de precipitación anual (Romero-Higareda et al., 2014). Por su parte, Flores et al. (2006) realizaron el análisis de datos climatológicos del área y sostienen que en las últimas décadas se han presentado varias sequías en el norte de Sinaloa, provocando una disminución de los volúmenes almacenados en las presas del sistema Fuerte-Mayo y, en consecuencia, de la superficie cultivada en los distritos de riego. Esta situación afecta por igual tanto a los agricultores de la región como a las actividades agropecuarias, por lo que la sequía puede ser un detonante para desencadenar problemas socioambientales.

Ante una situación climática potencialmente difícil, estudios realizados por el INIFAP en el norte del país han identificado razas de maíz adaptadas a condiciones deficientes de humedad, logrando ubicar un grupo que incluye a las razas Chapalote, Dulcillo del Noroeste, Tuxpeño Norteño, Cónico Norteño, Tablilla del Ocho y Gordo, los cuales podrían ser de utilidad en programas de mejoramiento de maíz adaptados a estrés por sequía (Ruiz et al., 2013). Por su parte, Ojeda-Bustamante et al. (2011) recomiendan hacer frente al cambio climático mediante acciones de adaptación en la región, como el uso de híbridos o variedades de ciclo más largo que las actuales con resistencia al estrés térmico, y la compactación del periodo de siembra hacia los meses más fríos.

\section{Aspectos Socioculturales}

La localidad de Jahuara II es una de las más importantes sindicaturas que forma parte de los siete
2013 temperature drops took place that caused frosts and considerable damages to crops like maize, beans and vegetables ${ }^{1}$.

The impact of both climate variables in regional agriculture is increasingly higher. Recent information points out that the generalized trend in northwestern México is of an increase in temperature and a decrease in the amount of annual rainfall (RomeroHigareda et al., 2014). In turn, Flores et al. (2006) performed the analysis of climatological data of the area and maintain that in recent decades there have been several droughts in northern Sinaloa, causing a decrease of the volumes stored in the dams of the Fuerte-Mayo system and, as consequence, of the surface cultivated in the irrigation districts. This situation affects equally both the farmers of the region and the agricultural and livestock activities, which is why drought can be a detonator to unchain socioenvironmental problems.

In face of a potentially difficult situation, studies performed by INIFAP in the north of the country have identified maize breeds adapted to deficient conditions of moisture, managing to locate a group that includes the Chapalote, Dulcillo del Noroeste, Tuxpeño Norteño, Cónico Norteño, Tablilla del Ocho and Gordo breeds, which could be useful in maize improvement programs for adapting to stress from drought (Ruiz et al., 2013). In their turn, Ojeda-Bustamante et al. (2011) recommend facing climate change through adaptation actions in the region, such as the use of hybrids or breeds of longer cycle than the current ones with resistance to thermic stress, and compacting the sowing period toward the colder months.

\section{Sociocultural aspects}

The locality of Jahuara II is one of the most important syndicates that are part of the seven Indigenous Ceremonial Centers in the municipality of El Fuerte. The inner organization is administratively composed of a municipal administrator, vigilance committee, people responsible for water, Mayo indigenous cobanaro, and development committee. The ejidatarios make decisions together through dialogue; they experience justice between groups, respecting their own decisions or by consensus. According to the farmers surveyed, of a total of 53 ejidatarios, 13 are women (69\% Mayos and $31 \%$ 
Centros Ceremoniales Indígenas del municipio de El Fuerte. La organización interna administrativamente se compone de un síndico municipal, comité de vigilancia, responsables del agua, cobanaro indígena mayo y un comité de desarrollo. Los ejidatarios toman las decisiones en conjunto a través del dialogo; viven la justicia entre grupos, respetando las decisiones propias o por consenso. De acuerdo con los agricultores encuestados, de un total de 53 ejidatarios, 13 son mujeres (69\% mayos y $31 \%$ mestizos) y 40 son hombres (55\% mayos, $42.5 \%$ mestizos y $2.5 \%$ rarámuris). Los ejidatarios mayos varones son los que predominan en la comunidad, seguidos de los mestizos. Los mayos conservan su identidad, su lengua materna y expresan parte de su cultura en las actividades agrícolas en torno al cultivo del maíz. La edad promedio de los ejidatarios de ambos grupos se encuentra entre 69.7 y 70.5 ańos, lo cual indica que son adultos mayores con un periodo de vida en la comunidad de 41 años en promedio. Aunque en su crecimiento poblacional es una comunidad relativamente nueva, en Jahuara II hay habitantes que provienen de diferentes municipios de Sinaloa y de otros estados de la República Mexicana. Sin embargo, algunas mayos deben su historia al desplazamiento de pueblos a valles debido a fenómenos naturales como crecientes de ríos o porque en sus rancherías se construyeron presas, como fue el caso de la L. Donaldo Colosio, localmente conocida como la presa Huites, en Choix, Sinaloa (López et al., 1996).

En materia de vivienda las casas de los ejidatarios son construidas con ladrillos y concreto, cuentan con menos de tres habitaciones y consideran que las que habitan son lugares adecuados para el desarrollo familiar. Tienen una tendencia a tener entre dos y tres hijos, cuyo número de integrantes permite tener menos gastos dentro del seno familiar. La principal actividad económica que desarrollan los ejidatarios mayos en la comunidad es la agricultura $(84 \%)$ y a los mestizos corresponde $66 \%$. Ambos grupos practican la agricultura de maíz y de otros cultivos, como trigo, sorgo, hortalizas, tomate y tomatillo. No se encontraron evidencias de que los ejidatarios practiquen el ancestral sistema milpa o siembra de policultivos; más bien prevalece el monocultivo de maíz, lo que sugiere que existe una simplificación de cultivos orientados al mercado. Una segunda actividad es la ganadería aunque en mínima proporción. Enseguida la actividad de la pesca, los mayos y mestizos se trasladan al
Mestizos) and 40 are men (55\% Mayos, $42.5 \%$ Mestizos and $2.5 \%$ Rarámuris). The male Mayo ejidatarios are the ones that predominate in the community, followed by the Mestizos. The Mayos conserve their identity, their mother tongue, and express part of their culture in agricultural activities around maize cultivation. The average age of ejidatarios of both groups is between 69.7 and 70.5 years, indicating that they are senior citizens with a life period in the community of 41 years in average. Although in their population growth, it is a relatively new community, in Jahuara II there are inhabitants that come from different municipalities in Sinaloa and other states of the Mexican Republic. However, some Mayos owe their history to the displacement of peoples to valleys due to natural phenomena such as river swells or because dams were built in their rancherias, as was the case of the L. Donaldo Colosio dam, locally known as the Huites dam, in Choix, Sinaloa (López et al., 1996).

In matters of housing, the ejidatarios' houses are built with bricks and concrete, have less than three rooms and consider that those they reside in are adequate places for family development. They have a tendency to have between two and three children, whose number of members allows having fewer expenses within the family nucleus. The main economic activity that Mayo ejidatarios develop in the community is agriculture (84\%) and the Mestizos 66 $\%$. Both groups practice maize agriculture and grow other crops, such as wheat, sorghum, vegetables, tomato and green tomato. No evidences were found that the ejidatarios practice the ancestral milpa system or cultivation of polycrops; rather, the monoculture of maize prevails, which suggests that there is a simplification of crops directed at the market. A second activity is livestock production although in a minimal proportion. Following the fishing activity, the Mayos and Mestizos are transported to Carrizo and dozens of kilometers to zones of water bodies in Sonora; however, economically it is not profitable; commerce activities are complementary jobs for the inhabitants. According to what has been exposed before, there is agreement between the primary economic activities of inhabitants in Jahuara II and what is reported by López-Torres and VargasHernández (2005).

On the other hand, there is a close relationship between farmers in Jahuara and the land they farm; 
Carrizo y a decenas de kilómetros a zonas de cuerpos de agua de Sonora; sin embargo, económicamente no es redituable; las actividades de comercio son trabajos complementarios para los pobladores. De acuerdo con lo expuesto anteriormente existe coincidencia de las actividades económicas primarias a las que se dedican los habitantes de Jahuara II, con lo reportado por López-Torres y Vargas-Hernández (2005).

En otro orden existe una relación estrecha del agricultor de Jahuara con la tierra que trabaja; los mayos poseen la propiedad de sus parcelas, mientras que los ejidatarios mestizos son dueños en $71.4 \%$ de los casos; las otras modalidades de tenencia de la tierra son las baldías y las rentadas. El fenómeno del rentismo en el norte de Sinaloa es mencionado por Cortés-Gregorio et al. (2013); no obstante, ha sido escasamente estudiado en el contexto de pérdida de identidad y territorio de los mayos.

De acuerdo con testimonios locales, los fundadores del ejido fueron los mayos, mientras que los mestizos se fueron "adueńado de parcelas", comprando terrenos de siembra a través del tiempo. La mayoría de los mayos obtuvieron sus terrenos agrícolas o parcelas por adjudicación $(87.5 \%$ ) y, en menor proporción, los mestizos (76.2\%); el restos de los ejidatarios por invasión de tierra. Para lograr el derecho a sus parcelas, la totalidad de los ejidatarios de ambos grupos cuentan con una escritura que les brinda certeza jurídica. Un porcentaje bajo de las tierras de ambos grupos se encuentran baldías por falta de riego para realizar las actividades agrícolas. En relación a la importancia de la agricultura para los ejidatarios, los mayos asumen que tienen más experiencia que los mestizos, por ser fundadores del ejido y su identidad más relacionada con la naturaleza de la agricultura, como la tierra, lluvia y siembra de cultivos (maíz $84.4 \%$ y en menor proporción sorgo $9.4 \%$ y soya $6.3 \%$ ). Los mestizos por su parte, se han adjudicado parcelas al comprar terrenos de siembra, con una visión más de tipo comercial de cultivos como el maíz, sorgo y soya. En lo referente a la superficie, según el tipo de agricultura, la de riego consta de 2.12 hectáreas promedio para los mayos y 2.38 hectáreas para los mestizos. En el caso de temporal, para los mayos se obtuvo en promedio 0.18 hectáreas y para los ejidatarios mestizos 0.23 hectáreas, lo que significa una disminución de las tierras de labor. the Mayos have ownership of their plots, while the Mestizo ejidatarios are owners in $71.4 \%$ of the cases; the other modalities of land ownership are barren lands and rented lands. The phenomenon of renting in northern Sinaloa is mentioned by Cortés-Gregorio et al. (2013); however, it has been scarcely studied within the context of loss of identity and territory of the Mayos.

According to local testimonies, the ejido founders were the Mayos, while the Mestizos "took over" plots, purchasing sowing lands through time. Most of the Mayos obtained their agricultural lands or plots from allocation $(87.5 \%)$ and, in lower proportion, the Mestizos also (76.2\%); the rest of the ejidatarios through land invasion. To attain the right to their plots, all of the ejidatarios from both groups have deeds that bring them legal certainty. A low percentage of lands from both groups were barren from lack of irrigation to perform their agricultural activities. Regarding the importance of agriculture for ejidatarios, the Mayos assume they have more experience than the Mestizos, because they are founders of the ejido and their identity is more connected to the nature of agriculture, such as land, rain, and crop sowing (maize $84.4 \%$ and in lower proportion, sorghum $9.4 \%$ and soy $6.3 \%$ ). The Mestizos, on their part, have appropriated plots when buying sowing lands, with a vision of crops like maize, sorghum and soy that is more commercial. Concerning the surface, according to the type of agriculture, that with irrigation has 2.12 hectares in average for the Mayos and 2.38 hectares for Mestizos. In the case of rainfed lands, for the Mayos there was an average of 0.18 hectares and Mestizo ejidatarios 0.23 hectares, which means a decrease in farming lands.

\section{Technological aspects}

Technical assistance is available from the moment that the ejidatario purchases inputs like seeds. However, the majority in the two groups have not received technological recommendations through any means, no information or training courses have reached them about seed selection, use of machinery, or how to face disasters from frosts and droughts; they describe that they have also not been trained in the management of pests or diseases. Therefore, problems of seed emergence, presence of local weeds such as 


\section{Aspectos tecnológicos}

La asistencia técnica se encuentra disponible desde el momento que el ejidatario compra insumos como la semilla. Sin embargo, la mayoría de los dos grupos no ha recibido recomendaciones de tecnología por ningún medio, no ha llegado información ni cursos de capacitación sobre la selección de la semilla, uso de la maquinaria, o cómo enfrentar siniestros por heladas y por sequía; refieren que tampoco se han capacitado en el manejo de plagas o enfermedades. Por ello, problemas de emergencia de la semilla, presencia de malezas locales como "el girasol silvestre", "estafiate" y el "zacate Johnson" que abundan en el mes de febrero y abril, los propios agricultores lo resuelven. Ambos grupos solo visitan al técnico cuando las enfermedades son desconocidas; para los mayos el agricultor cuenta con más conocimiento del proceso del cultivo, mientras que los ejidatarios mestizos incluyen a los técnicos agrícolas y argumentan que ambos cuentan con suficiente conocimiento de la agricultura de maíz. Instituciones de Investigación como el INIFAP ofrecen guías técnicas, pero no los servicios de extensionismo que acompañen la asesoría; esta labor y el suministro de insumos recaen en las agroempresas locales y los servicios privados.

Una forma gráfica de expresar el cúmulo del conocimiento local en el tiempo y la distribución del trabajo social en el campo es a través del calendario de actividades agrícolas donde se ubica el manejo de los cultivos por los pobladores, según las condiciones ambientales prevalecientes. Desde un enfoque etnoecológico y en trabajos realizados con pueblos indígenas ha quedado en evidencia la trascendencia de la distribución de actividades, insumos empleados y formas de trabajo utilizadas en torno a la agricultura (Lara et al., 2002; 2012). El calendario agrícola de Jahuara II no es la excepción; ambos grupos de agricultores realizan actividades, como la preparación del terreno que incluye piqueo, rastreo, nivelación, marca para siembra, bordeo-canalización, tumba de bordos-canales, escarificación y limpia de canales; y control de plagas mediante aplicación de químico. Para la cosecha se realiza la trilla del maíz que va acompañado del acarreo del grano con destino a la comercialización. "wild sunflower", "wormwood" and "Johnson grass", which are abundant during the months of February and April, are solved by the farmers themselves. Both groups only visit the technician when the diseases are unknown; for the Mayos the farmer has more knowledge of the cultivation process, while the Mestizo ejidatarios include agricultural technicians and argue that both have enough knowledge of maize agriculture. Research Institutions such as INIFAP offer technical guides, but not the services of extension work that come with the consulting; this task and the supply of inputs fall on the local agribusinesses and private services.

A graphic form of expressing the accumulation of local knowledge in time and distribution of social work in the field is through a calendar of agricultural activities where the management of crops by inhabitants is described, according to the prevalent environmental conditions. From an ethnoecological approach and in studies carried out with indigenous peoples there has been evidence of the transcendence of the distribution of activities, inputs used and ways of work used around agriculture (Lara et al., 2002; 2012). The Jahuara II agricultural calendar is not the exception; both groups of farmers perform activities such a preparing the land, including picking, dragging, levelling, marking for sowing, bordering-channeling, establishing bermschannels, scarification, and channel cleaning; and pest control through applying chemicals. For the harvest, maize threshing is done which is accompanied by grain transport with destination to commercialization.

\section{Seed used and yield per surface}

Maize agriculture in the Valle del Carrizo is significant. In Jahuara II, in 2013, the Mayos sowed $12.5 \%$ of Creole maize, $71.9 \%$ of improved seed and of both seeds; in the remaining $15.6 \%$ the Mestizos said they sowed $100 \%$ of improved maize. Lazos (2008) mentions that in the valleys and flatlands of Sinaloa, farmers since 1990 depend on the purchase of seeds from transnational companies, while in the sierras the producers continue using a mixture of hybrid and local traditional maize breeds. In this sense, Lazos explains that at the state level $93 \%$ of the surface sown with maize uses improved seed, while 


\section{Semilla utilizada y rendimiento por superficie}

La agricultura de maíz en el Valle del Carrizo es significativa. En Jahuara II, en 2013, los mayos sembraron $12.5 \%$ de maíz criollo, $71.9 \%$ de semilla mejorada y de ambas semillas; en el $15.6 \%$ restante los mestizos dijeron sembrar $100 \%$ de maíz mejorado. Lazos (2008) menciona que en los valles y llanos de Sinaloa los agricultores desde 1990 dependen de la compra de semillas a compañías trasnacionales, mientras que en las sierras los productores continúan con una mezcla de maíces híbridos y locales tradicionales. En ese sentido Lazos explica que a nivel estatal $93 \%$ de la superficie sembrada de maíz utiliza semilla mejorada, mientras que $7 \%$ siembra poblaciones de maíces criollos o variedades hibridas criollizadas. Esta situación se asemeja proporcionalmente a la escala local de Jahuara.

Con respecto al color de maíz, los ejidatarios mestizos prefieren el blanco, que sembraron en un $95.2 \%$, comparado con los mayos, que lo hicieron en $90.6 \%$; el resto corresponde a maíz amarillo. Los mayos también gustan del color blanco porque es un grano resistente a plagas y enfermedades, y tiene buena productividad por hectárea; por su parte, los mestizos eligen también este color porque es de costo bajo y productivo, lo que confirma la aceptación sociocultural de este grano por ambos grupos de agricultores, quienes consiguen la semilla en empresas de la región o visitan a comerciantes para comprarla. Aunque no se precisaron los nombres comunes de los maíces criollos utilizados en Jahuara, Espinosa de la Mora (2005) menciona que en el norte de Sinaloa los maíces que se utilizan tradicionalmente en las comunidades de Choix, municipio contiguo a El Fuerte, son "coriquero", "chapalote" y "chori". Desde la óptica de modelo de mercado estos maíces criollos no cumplen con las exigencias de productividad y de elaboración de alimentos a gran escala. No obstante, si se considera este germoplasma local como patrimonio biocultural (Boege, 2008), existe una correspondencia genética de los maíces nativos y por nombre común con las razas tropicales identificadas y distribuidas en regiones de Sinaloa, Sonora y Chihuahua, como son: Bofo, Blandito de Sonora, Dulcillo del noroeste, Harinoso del ocho, Onaveño, Tabloncillo y Perla (González et al., 2013).

El rendimiento de grano por superficie es la variable de producción agrícola de mayor interés. Según
$7 \%$ sows populations of Creole maize or creolized hybrid varieties. This situation is proportionally similar to the local scale at Jahuara.

With regards to the color of maize, the Mestizo ejidatarios prefer white, which they sowed in $95.2 \%$, compared to the Mayos, who did it in $90.6 \%$; the rest corresponds to yellow maize. The Mayos also like white maize because it is a grain resistant to pests and diseases, and has good productivity per hectare; in their turn, the Mestizos also choose this color because it is of low cost and productive, which confirms the sociocultural acceptance of this grain by both groups of farmers, who get the seed from companies in the region or visit traders to purchase it. Although the common names of the Creole maize breeds used in Jahuara were not specified, Espinosa de la Mora (2005) mentions that in northern Sinaloa the maize breeds that are traditionally used in the Choix communities, municipality neighboring El Fuerte, are "coriquero", "chapalote" and "chori". From the view of the market model these Creole maize breeds do not fulfill the demands of productivity and food elaboration at a large scale. However, if this local germplasm is considered as biocultural patrimony (Boege, 2008), there is genetic correspondence of native maize breeds and by common name with the tropical breeds identified and distributed in regions of Sinaloa, Sonora and Chihuahua, such as: Bofo, Blandito from Sonora, Dulcillo from the northwest, Harinoso del ocho, Onaveño, Tabloncillo and Perla (González et al., 2013).

The grain yield per surface is the agricultural production variable of greatest interest. According to their perception, during 2013 the Mayo ejidatarios obtained an average of $5258 \mathrm{~kg} / \mathrm{ha}$ under irrigation conditions, amount higher than the Mestizos, who obtained a mean of $4380 \mathrm{~kg} / \mathrm{ha}$. Regarding rainfed cultivation, the Mayo ejidatarios obtained a mean of $328 \mathrm{~kg} / \mathrm{ha}$ of maize, higher than the Mestizos who obtained in average $181 \mathrm{~kg} / \mathrm{ha}$. However, both groups perceive them as low grain yields per surface, although comparatively the Mayo ejidatarios obtained a better production from the harvest. In order to increase the maize yields, the agricultural research institutions continue looking for native materials that have potentially good yields. In a study of agronomic characterization of maize breeds from the northeast there is one kind of genetic material that stands out destined to the white grain market 
su percepción, durante 2013 los ejidatarios mayos obtuvieron un promedio de $5258 \mathrm{~kg} / \mathrm{ha}$ en condiciones de riego, cantidad superior a los mestizos, que obtuvieron una media de $4380 \mathrm{~kg} / \mathrm{ha}$. En lo que corresponde a la siembra de temporal, los ejidatarios mayos obtuvieron una media de $328 \mathrm{~kg} / \mathrm{ha}$ de maíz, superior a los mestizos que obtuvieron en promedio de $181 \mathrm{~kg} / \mathrm{ha}$. Sin embargo, ambos grupos, perciben como bajos rendimientos de grano por superficie, aunque comparativamente los ejidatarios mayos obtuvieron mejor producción de la cosecha. Para incrementar los rendimientos de maíz, las instituciones de investigación agrícola, continúan buscando materiales nativos potencialmente rendidores. En un estudio de caracterización agronómica de maíces del noroccidente se destaca un material genético destinado al mercado de grano blanco para "pozole" y que resultó mejor al resto de la raza Ancho y a los de las razas Elotes Occidentales, Elotero de Sinaloa y Bofo, utilizados también para "pozole" y "elote" (Martín et al., 2008).

El manejo del cultivo de maíz por mayos y mestizos revela que existe un conocimiento tradicional que ha ido incorporando y adaptando elementos tecnológicos modernos, como la semilla mejorada, según los propios criterios locales, o sean las necesidades de adaptación al conocimiento ecológico tradicional de sus sistemas agrícolas, como lo efectúan los Guarijíos de Sonora (Colin et al., 2015) u otros grupos como los nahuas y campesinos de México (Lara et al., 2005).

\section{Aspectos financieros}

De los ejidatarios mayos, $72 \%$ solicita dinero prestado para llevar a cabo la siembra u otras actividades agrícolas, debido a que con lo obtenido en la cosecha anterior no es suficiente para ahorrar para la próxima siembra. La misma situación problemática en menor proporción (57\%) se presenta en los ejidatarios mestizos. En ambos casos, según su apreciación necesitan suficiente capital para cubrir los gastos para la siembra de maíz. Los costos promedio considerados para la siembra y producción de una hectárea de maíz de riego abarcan diversos rubros tecnológicos como labores, insumos, asistencia técnica, entre otros. En suma total, en el ciclo 2013 los ejidatarios mayos invirtieron $\$ 13459$ (M.N.) desde la siembra del grano hasta la comercialización del maíz; en cambio, los mestizos necesitaron disponer de \$14 017 for "pozole" and which was better than the rest of the Ancho breed and to the breeds Elotes Occidentales, Elotero de Sinaloa and Bofo, also used for "pozole" and "elote" (Martín et al., 2008).

Maize cultivation management by Mayos and Mestizos reveals that there is traditional knowledge that has been incorporating and adapting modern technological elements, such as improved seed, according to the local criteria themselves, or based on the needs for adaptation to traditional ecological knowledge of their agricultural systems, such as the Guarijíos from Sonora (Colin et al., 2015) or other groups like the Nahuas and peasants from México (Lara et al., 2005).

\section{Financial aspects}

Of the Mayo ejidatarios, $72 \%$ request money in loans to carry out sowing or other agricultural activities, because what was obtained with the prior harvest is not sufficient to save for the next sowing. The same problematic situation in lower proportion (57 \%) is present among Mestizo ejidatarios. In both cases, according to their assessment they need sufficient capital to cover the expenses for maize cultivation. The average costs considered for sowing and production of one hectare of maize under irrigation cover diverse technological aspects such as tasks, inputs, technical assistance, among others. In total sum, during the 2013 cycle the Mayo ejidatarios invested \$13 459 (MX pesos) from grain sowing to maize commercialization; instead, the Mestizos needed \$14 017 (MX pesos); averaging the values, there is an investment cost per hectare of $\$ 12838.58$ (M.N.) or USD $\$ 987.58$ for the two groups (Table 1).

When performing the cost-benefit analysis of a hectare of maize, a value lower than one was estimated. For each peso invested, a benefit of 0.33 pesos was obtained (Table 2). The production costs are of economic interest for both groups of ejidatarios from Jahuara II, where the seed for sowing, fertilizers and irrigation are the inputs that demand highest investment. This situation agrees with what was mentioned by Chauvet and Lazos (2014), who, according to the productive Fall-Winter cycle and cultivation management performed, detected that in general the farmers from Sinaloa didn't have problems with pests or weeds. The main inputs that demand 
(M.N.); promediando los valores se tiene un costo de inversión por hectárea de $\$ 12838.58$ (M.N.) o USD 987.58 para los dos grupos (Cuadro 1).

Al efectuar el análisis de costo-beneficio de una hectárea de maíz se estimó un valor menor a uno. Por cada peso invertido se obtuvo un beneficio de 0.33 pesos (Cuadro 2). Los costos de producción son de interés económico para ambos grupos de ejidatarios de Jahuara II, donde la semilla para la siembra, fertilizantes y el riego son los insumos que demandan mayor inversión. Esta situación coincide con lo mencionado por Chauvet y Lazos (2014), quienes de acuerdo con el ciclo productivo otońo-invierno y al manejo del cultivo efectuado detectaron que en general los agricultores de Sinaloa no tienen problemas con plagas ni con malezas. Los principales insumos que demandan atención son las semillas y fertilizantes, que significan hasta $70 \%$ del gasto de inversión, aunada al consumo de altas cantidades de agua.

\section{Percepción de la problemática agrícola y escenarios}

En términos productivos los agricultores consideran que las hectáreas de producción del maíz tanto de riego como de temporal no son suficientes para mantener la familia. Desde los ańos noventa, en su opinión no se ha sostenido buena cosecha y los terrenos necesitan preparación, fertilizantes, nutrientes y riegos adecuados para alcanzar una buena producción de grano. Los gastos empleados en las labores son elevados y los organismos oficiales poco se preocupan de los problemas que enfrenta el agricultor.

Los ejidatarios mayos y mestizos coinciden en que la producción del maíz está destinada para la venta y así capitalizarse para saldar cuentas contraídas; la comercialización de grano lo hacen con empresas cercanas a la comunidad, almacenes del Valle del Carrizo y comerciantes locales. Los ejidatarios llegan a utilizar dinero prestado para el cultivo. Para ello recurren a amigos y familiares, y como última opción solicitan crédito al banco; esta institución brinda facilidades para la obtención de un crédito, pero la tasa de interés es muy alta.

$\mathrm{El}$ aspecto económico es el problema principal que afecta a Jahuara II. La falta de apoyos para el campo orilla al ejidatario a rentar la parcela, a vender la tierra, e incluso a demandas por derechos de este tipo de casos se siguen resolviendo en los tribunales. attention are seeds and fertilizers, which mean up to $70 \%$ of the investment expenditure, in addition to the consumption of high amounts of water.

\section{Perception of the agricultural problematic and scenarios}

In productive terms the farmers consider that the maize production hectares both under irrigation and rainfed are not sufficient to support the family. Since the 1990s, in their opinion, there hasn't been a good harvest and the lands need preparation, fertilizers, nutrients and adequate irrigation to attain good grain production. The expenses used in the tasks are high and the official organizations do not worry much about the problems that farmers face.

The Mayo and Mestizo ejidatarios agree that maize production is destined for sale and thus become capitalized to pay pending bills; grain commercialization is done by companies close to the community, stores in Valle del Carrizo and local traders. The ejidatarios sometimes use money lent for the cultivation. For this purpose, they resort to friends and family members, and as a last option they request credit from the bank; this institution provides opportunities to obtain credit, but the interest rate is very high.

The economic aspect is the main problem that affects Jahuara II. The lack of backing for the countryside pushes ejidatarios to rent plots, sell lands, and even pursue lawsuits over rights of this type of cases which are still being solved in courts. The ejidatarios have also been harmed by agricultural policies that the State has implemented, such as the Constitutional Article 27 reform which had the tendency to privatize ejido lands. The joint problem of rent and sale of plots has increased recently from two causes: lack of options to make land produce and of participation in official programs of agricultural and livestock character, although there is support from federal subsidies; without a doubt, the problem continues to be the commercialization of the grain and the high cost of production of agricultural activities. The local situation is difficult and the unemployment, the rent and sale of plots, the same as migration, are phenomena that have increased in the last 10 years; this scenario was also detected by López-Torres and Vargas-Hernández (2005). 
Cuadro 1. Estimación promedio de costos de producción por hectárea del cultivo de maíz de riego ciclo agrícola 2013 Jahuara II, el Fuerte, Sinaloa.

Table 1. Average estimation of production costs per hectare for irrigated maize cultivation, 2013 agricultural cycle, Jahuara II, El Fuerte, Sinaloa.

\begin{tabular}{|c|c|c|c|c|c|}
\hline \multicolumn{2}{|l|}{ Actividades } & Cantidad & $\begin{array}{c}\text { Ejidatario } \\
\text { Mayo } \\
(\$)\end{array}$ & $\begin{array}{c}\text { Ejidatario } \\
\text { Mestizo } \\
(\$)\end{array}$ & $\begin{array}{c}\text { Promedio } \\
(\$)\end{array}$ \\
\hline \multicolumn{6}{|l|}{ a) Preparación del terreno } \\
\hline Piqueo & & 1 & 387.00 & 511.36 & 449.18 \\
\hline Rastreo & & 1 & 429.00 & 356.81 & 392.90 \\
\hline Nivelación & & 1 & 242.00 & 277.00 & 260.00 \\
\hline Marca para siembra & & 1 & 329.00 & 309.00 & 319.00 \\
\hline Bordeo-canalización & & 1 & 150.00 & 215.00 & 182.50 \\
\hline Tumba de bordos-canales & & 1 & 158.00 & 179.00 & 168.50 \\
\hline Escarificación & & 1 & 335.00 & 315.00 & 325.00 \\
\hline \multirow[t]{2}{*}{ Limpia de canales } & & 1 & 164.00 & 159.00 & 161.50 \\
\hline & Subtotal & & 2194.00 & 2322.17 & 2258.58 \\
\hline \multicolumn{6}{|l|}{ b) Siembra } \\
\hline Semilla & & $22.5(\mathrm{~kg})$ & 2900.00 & 2727.00 & 2813.50 \\
\hline Siembra & & 1 & 400.00 & 436.00 & 418.00 \\
\hline \multirow[t]{2}{*}{ Permiso } & & 1 & 175.00 & 2000.00 & 187.50 \\
\hline & Subtotal & & 3475.00 & 5163.00 & 3419.00 \\
\hline \multicolumn{6}{|l|}{ c) Fertilización } \\
\hline Fertilizante & & 1 & 390.00 & 375.00 & 382.50 \\
\hline \multirow[t]{2}{*}{ Amoniaco } & & 1 & 796.00 & 350.00 & 573.00 \\
\hline & Subtotal & & 1186.00 & 725.00 & 955.50 \\
\hline \multicolumn{6}{|l|}{ d) Labores culturales } \\
\hline Cultivo & & & 377.00 & 356.00 & 366.50 \\
\hline Deshierbe & & 1 & 250.00 & 300.00 & 275.00 \\
\hline \multirow[t]{2}{*}{ Abrir surco para riego } & & 1 & 277.00 & 195.00 & 236.00 \\
\hline & Subtotal & & 904.00 & 851.00 & 877.50 \\
\hline \multicolumn{6}{|l|}{ e) Riegos } \\
\hline Cuota de riego & & & 2000.00 & 1800.00 & 1900.00 \\
\hline \multicolumn{6}{|c|}{ f) Control plagas-enfermedades } \\
\hline Control químico & & 1 & 550.00 & 275.00 & 412.50 \\
\hline \multirow[t]{2}{*}{ Insecticida } & & 1 & 450.00 & 240.00 & 345.00 \\
\hline & Subtotal & & 1000.00 & 515.00 & 757.50 \\
\hline \multicolumn{6}{|l|}{ g) Cosecha } \\
\hline Trilla & & 1 & 1500.00 & 1481.00 & 1490.50 \\
\hline \multirow[t]{2}{*}{ Acarrreo } & & 1 & 500.00 & 466.00 & 483.00 \\
\hline & Subtotal & & 2000.00 & 1947.00 & 1973.50 \\
\hline \multicolumn{6}{|l|}{ h) Diversos } \\
\hline Asistencia técnica integral & & & 200.00 & 144.00 & 172.00 \\
\hline \multirow[t]{2}{*}{ Seguro agrícola } & & 1 hectárea & 500.00 & 550.00 & 525.00 \\
\hline & Subtotal & & 700.00 & 694.00 & 697.00 \\
\hline Costo Total \$ (pesos M.N) & & & 13459.00 & 14017.17 & 12838.58 \\
\hline Costo Total \$ USD* & & & 1035.31 & 1078.24 & 987.58 \\
\hline
\end{tabular}

Fuente: Información de campo Jahuara II, ciclo agrícola 2013. *Tipo de Cambio 1 USD $=13$ pesos aprox. en 2014. Source: Field information from Jahuara II, 2013 agricultural cycle. *Exchange Rate 1 USD =13 pesos approximately in 2014 . 
Cuadro 2. Estimación de la relación costo-beneficio de una hectárea de maíz en Jahuara II, ciclo 2013.

Table 2. Cost-benefit relation estimation of a hectare of maize in Jahuara II, 2013 cycle.

\begin{tabular}{|c|c|c|}
\hline Referencias del cultivo de maíz (ciclo agrícola 2013) & & \\
\hline \multirow[t]{2}{*}{ Rendimiento estimado en parcela (ton/ha) } & 4.81 & 4.81 \\
\hline & $\begin{array}{l}\text { Pesos } \\
\text { (M.N.) }\end{array}$ & USD \\
\hline Apoyo de PROCAMPO (\$/ton) & 963.00 & 74.07 \\
\hline \multirow[t]{2}{*}{ Precio promedio de venta local (\$/ton) } & 3350.00 & 257.69 \\
\hline & & \\
\hline 1. Costos totales de producción $(\$ / \mathrm{ha})$ & $\begin{array}{c}\text { Pesos (M.N.) } \\
12838.58\end{array}$ & $\begin{array}{l}\text { USD } \\
987.58\end{array}$ \\
\hline 2. Beneficio bruto (rendimiento ha $x$ precio de venta) + PROCAMPO ( $\$ /$ ha) & 17079.85 & 1313.83 \\
\hline 3. Beneficio neto $(2-1)(\$ / \mathrm{ha})$ & 4241.27 & 326.25 \\
\hline 4. Relación beneficio/costo (3/1) (beneficio por peso $\$$ invertido) & 0.33 & 0.33 \\
\hline 5. Costo por tonelada ( $1 /$ rendimiento por ha) $(\$ /$ ton $)$ & 696.32 & 53.56 \\
\hline
\end{tabular}

Fuente: Información de campo Jahuara II, ciclo agrícola 2013. *Tipo de Cambio 1 USD=3 pesos aprox. en 2014. Source: Field information from Jahuara II, 2013 agricultural cycle. *Exchange Rate 1 USD=13 pesos approximately in 2014.

A los ejidatarios también les han perjudicado las políticas agrícolas que implementó el Estado, como la reforma al Artículo 27 Constitucional cuya tendencia era la privatización de las tierras del ejido. El problema conjunto de la renta y la venta de parcelas se ha acrecentado últimamente por dos causas: falta de opciones para producir la tierra y de participación en programas oficiales de carácter agropecuario, aunque existe apoyo de subsidios federales; sin duda el problema continúa siendo la comercialización del grano y el elevado costo de producción de las actividades agrícolas. La situación local es difícil y el desempleo, la renta y venta de parcelas, al igual que la emigración, son fenómenos que se han acrecentado en los últimos 10 años; este escenario también fue detectado por López-Torres y Vargas-Hernández (2005).

Los pequeños agricultores mayos y mestizos cada vez practican menos agricultura de tipo comercial, ya que es más difícil para ellos conseguir créditos para aperos agrícolas, semillas, pago de agua, o bien, encarar sequías prolongadas o problemas de suelos agrícolas. Ante tal panorama, el rentismo es la solución por la que muchos ejidatarios optan y al mismo tiempo les permite conservar la tierra: su base patrimonial. No obstante, hay muchos mayos que se ven forzados a vender sus tierras debido a alguna enfermedad o por la necesidad de adquirir bienes diversos, lo cual orilla a muchos indígenas, ya sin patrimonio alguno, a vender su fuerza de trabajo empleándose como jornaleros agrícolas. La situación de pobreza permanente que los mayos padecen ha hecho que sean blanco
The small-scale Mayo and Mestizo farmers practice agriculture of the commercial type increasingly less, since it is more difficult for them to get credits for agricultural tools, seeds, water payments, or else face prolonged droughts or agricultural soil problems. Facing this panorama, renting is the solution that many ejidatarios opt for and at the same time allows them to conserve the land: their patrimonial base. However, there are many Mayos that are forced to sell their lands due to some illness or from the need to acquire various goods, which drives many indigenous people, left with no more patrimony, to sell their workforce by hiring out as agricultural day laborers. The situation of permanent poverty that the Mayos endure makes them target of new hoarders, thus promoting emerging land-ownership of large estate, the greatest threat that, paradoxically, the agrarian reform wanted to eradicate (Moctezuma and López, 2007).

The globalization process has generated vertiginous changes of the social, economic and technological type in recent decades, and has had an effect on the way of life of the Mayos, but has benefitted primarily the large farmers of Mestizo origin, who have economic, technological resources, and means of production, such as lands, irrigation water, machinery and agrichemical inputs that have positioned modern agriculture in the valleys of Sinaloa on the first levels in crops such as maize, vegetables and fruit trees. This model of agricultural modernization of high inputs and for commercial 
de nuevos acaparadores, propiciando así un latifundismo emergente, la amenaza mayor que paradójicamente la reforma agraria quiso erradicar (Moctezuma y López, 2007).

El proceso de globalización ha generado cambios vertiginosos de tipo social, económico y tecnológico en las últimas décadas, y ha repercutido en el modo de vida de los mayos, pero ha beneficiado principalmente a los grandes agricultores de origen mestizo, quienes cuentan con recursos económicos, tecnológicos y medios de producción, como tierras, agua de riego, maquinaria e insumos agroquímicos que han posicionado a la agricultura moderna de los valles de Sinaloa en los primeros niveles en cultivos como maíz, hortalizas, frutales. Este modelo de modernización agrícola de altos insumos y de propósitos comerciales especializado en maíz y hortalizas en los valles agrícolas de Sinaloa (Espinosa de la Mora, 2005; Carrillo, 2013; Chauvet y Lazos, 2014) contrasta de origen con el modelo tradicional de manejo agrícola y de aprovechamiento familiar de los recursos naturales propio de los mayo, guarijíos y otros pueblos de economía campesina que lo practican en desventaja en valles y lomeríos del noroeste del país (Moctezuma y Aguilar, 2013; Colin et al., 2015). La erosión del conocimiento asociado a la agricultura tradicional, invariablemente conduce a la pérdida de la diversidad de maíces criollos de la región, que es patrimonio biocultural de los mayos y los mestizos.

Por otra parte, los problemas relacionados con el territorio y la pérdida de los conocimientos de los recursos naturales por las nuevas generaciones de jóvenes mayos que ya no se dedican a estas actividades, tal como ocurre en regiones del sur de México (Aguilar, Illsley y Marielle, 2003), propicia que esta vital fuerza productiva busque opciones de empleo diversas o migre a áreas urbanas y se queden en las unidades familiares de las localidades, principalmente las personas de mayor edad. No menos importante en la región es la compleja problemática derivada del fenómeno social del narcotráfico (Astorga, 2012), cuyas consecuencias socioeconómicas han repercutido en los diferentes sectores productivos, así como en las comunidades de mayos y mestizas.

Siendo el territorio y los recursos naturales la base de sustento de los mayos, la problemática de las últimas décadas ha girado en torno a su paulatina transformación o cambio de uso del suelo del territorio a partir del impulso a la agroindustria y purposes specialized in maize and vegetables in the agricultural valleys of Sinaloa (Espinosa de la Mora, 2005; Carrillo, 2013; Chauvet and Lazos, 2014) contrasts from origin with the traditional model of agricultural management and family exploitation of natural resources of the Mayo, Guarijíos and other peoples based on peasant economy that practice it at a disadvantage in valleys and hills in the northwest of the country (Moctezuma and Aguilar, 2013; Colin et al., 2015). The erosion of knowledge associated to traditional agriculture invariably leads to the loss of diversity of Creole maize breeds from the region, which is biocultural patrimony of the Mayos and Mestizos.

On the other hand, the problems related to territory and the loss of knowledge about natural resources by the new generations of Mayo youth who are no longer devoted to these activities, as it happens in regions in the south of México (Aguilar, Illsley and Marielle, 2003), fosters for this vital productive force to seek diverse employment options or to migrate to urban areas and remain in the family units of the localities, primarily older people. Not least important in the region is the complex problematic derived from the social phenomenon of drug trafficking (Astorga, 2012), which has socioeconomic consequences that have an effect on different productive sectors, as well as on the Mayo and Mestizo communities.

With the territory and natural resources being the basis of sustenance of the Mayos, the problematic of recent decades has revolved around their gradual transformation or change in land use of the territory from the promotion of agribusiness and the consequent devastation of the forest, situation that weakened the exploitation and traditional knowledge of agriculture and natural resources. Traditional agriculture that dominated up until the 1960s went to another highly technified type, characteristic of the central valleys and medium productive zones, known as the "green revolution" (Hewit de Alcántara, 1978). This scenario reconfigured the countryside of northern Sinaloa and converted it with the impulse of agribusinesses, especially with crops like sugar cane (practically extinct now) and vegetables, in an economic development pole of sustained importance. Currently, with no other option, the Mayo communities share in disadvantage part of the territory from their ancestors, transformed into the best areas of agricultural potential, but in the hands 
la consecuente devastación del monte, situación que debilitó el aprovechamiento y conocimiento tradicional de la agricultura y los recursos naturales. La agricultura tradicional que dominó hasta los años sesenta del siglo XX pasó a otra de tipo altamente tecnificada propia de los valles centrales y las zonas medias productivas, conocida como la "revolución verde" (Hewit de Alcántara, 1978). Este escenario reconfiguró el campo del norte de Sinaloa y lo convirtió con el impulso de las agroindustrias, en especial con cultivos como la caña de azúcar (prácticamente ahora extinto) y las hortalizas, en un polo de desarrollo económico y de sostenida importancia. Actualmente, sin otra opción, las comunidades mayo comparten en desventaja parte del territorio de sus ancestros, convertido en las mejores áreas de potencial agrícola, pero en manos de poblaciones mestizas y otros grupos migrantes que se fueron asentando en la región hace ya algunas décadas.

\section{Conclusiones}

La presente investigación de enfoque mixto llevada a cabo en la comunidad de Jahuara II logró recopilar información de los componentes ambientales, sociales, culturales y económicos de la agricultura de maíz practicada por mayos y mestizos. Las principales limitantes ambientales para la agricultura de maíz en condiciones de riego y temporal son la escasa y errática precipitación en los meses de julio a octubre que imposibilitan un adecuado proceso productivo y los altos niveles de siniestralidad. Los agricultores identifican a las sequías como principal problema para la producción de maíz. La presencia de siniestros climatológicos, como las bajas temperaturas y la falta de agua, ha contribuido a que los ejidatarios mayos y mestizos decidan sembrar otros cultivos de importancia comercial como el sorgo y el trigo.

En el plano sociocultural los ejidatarios mayos conservan elementos que dan razón a su identidad, como son las prácticas del conocimiento agrícola que incluyen fechas de siembra y la calendarización de actividades de manera anual. Ambos grupos de ejidatarios mayos y mestizos llevan a cabo diversas prácticas agrícolas dentro de un calendario de la agricultura de maíz, socialmente definido. Tecnológicamente los dos grupos de ejidatarios practican una agricultura tecnificada similar en sus componentes; sin embargo, la semilla criolla de maíz es preferentemente empleada por los mayos. La percepción del rendimiento of Mestizo populations and other migrant groups which settled into the region some decades ago.

\section{Conclusions}

This study of mixed approach carried out in a community of Jahuara II managed to gather information from the environmental, social, cultural and economic components of maize agriculture practiced by Mayos and Mestizos. The main environmental limitations for maize agriculture under irrigation and rainfed conditions are the scarce and erratic rainfall during the months of July to October that make an adequate productive process impossible and the high levels of disaster rates. The farmers identify droughts as the main problem for maize production. The presence of climate disasters, such as the low temperatures and lack of water, has contributed to Mayo and Mestizo ejidatarios deciding to sow other crops of commercial importance such as sorghum and wheat.

In the sociocultural aspect, Mayo ejidatarios conserve elements that explain their identity, such as the practices of agricultural knowledge that include sowing dates and scheduling of activities manually. Both groups of Mayo and Mestizo ejidatarios carry out various agricultural practices within a calendar of maize agriculture that is socially defined. Technologically, the two groups of ejidatarios practice technified agriculture similar in its components; however, the Creole maize seed is used preferably by the Mayos. The perception of yield obtained during the 2013 harvest under the irrigation system by the Mayos was good ( $5258 \mathrm{~kg} / \mathrm{ha}$ in average) and slightly higher than that of Mestizos (4380 kg/ha). A similar situation was present under rainfed conditions. The differences in production are influenced by management conditions of the crop. In the economic plane, based on the cost/benefit analysis a value of 0.33 was found, which is favorable, although the production costs per hectare in both groups of farmers is high.

The study detected that the Mayos have been gradually losing cultivation lands because of economic reasons, have ceased to sow surfaces with Creole maize breeds and have abandoned traditional agricultural practices associated to maize production. The erosion of knowledge about traditional agriculture favors the possible extinction 
obtenido durante la cosecha 2013 bajo el sistema de riego por los mayos fue buena $(5258 \mathrm{~kg} / \mathrm{ha}$ en promedio) y ligeramente superior a los de los mestizos (4380 kg/ha). Similar situación se presentó bajo temporal. Las diferencias en la producción son influenciadas por condiciones de manejo del cultivo. En el plano económico se encontró con base al análisis de costo/beneficio un valor de 0.33 , el cual es favorable, aunque los costos de producción por hectárea en ambos grupos de agricultores, es alto.

El estudio detectó que los mayos han perdido terrenos de siembra paulatinamente por razones económicas, han dejado de sembrar superficies de maíz criollo y han abandonado prácticas agrícolas tradicionales asociadas a la producción de maíz. La erosión del conocimiento de la agricultura tradicional propicia la posible extinción de la diversidad de los maíces criollos, que es el patrimonio biocultural de los mayo de la región, cuyo potencial genético es reconocido y con expectativa favorable de estudio por los centros de investigación. Es necesario recuperar y valorar los conocimientos ancestrales del manejo de la agricultura del maíz que forman parte de la identidad de este grupo cultural que habita en la región del noroeste de México.

Existe un capital humano propio de los mayos y mestizos, quienes desarrollan actividades económicas no solo trabajando en el campo propio o como jornaleros agrícolas, sino en nuevas actividades como proyectos productivos; sin embargo, no se descarta que la fuerza productiva joven tienda a buscar opciones de empleo diversas o mugre a áreas urbanas, propiciando que se queden en las unidades familiares de la localidad, principalmente las personas de mayor edad.

\section{Notas}

${ }^{1}$ Daña helada a cultivos en El Carrizo y Guasave, Sinaloa. El Diario. Dom, 13 Ene 2013. http:// www.eldiariodesinaloa.com/movil/publicacion. php?id=98472 * Frost damage on crops in El Carrizo and Guasave, Sinaloa. El Diario. Dom, 13 Ene 2013. http://www.eldiariodesinaloa.com/movil/ publicacion.php?id=98472

\section{Literatura Citada}

Aguilar, Jasmín, Catarina Illsley, y Catherine Marielle. 2003. El sistema agrícola de maíz y sus procesos técnicos. In: Gustavo of diversity in the Creole maize breeds, which is the biocultural patrimony of the Mayos in the region, whose genetic potential is recognized and with a favorable expectation of study by research centers. It is necessary to recover and value the ancestral knowledge of maize agriculture management that is part of the identity of this cultural group that resides in the northwestern region of México.

There is Mayo and Mestizo human capital, who develop economic activities that are not only working their own field or as agricultural day laborers, but rather in new activities like productive projects; however, it is not ruled out that the young productive force will tend to seek various employment options or migrate to urban areas, fostering for mainly the older people to stay in the location's family units.

$$
\text { - End of the English version - }
$$

Esteva y Catherine Marielle (coords) Sin Maíz no hay País. México. Consejo Nacional para la Cultura y las Artes, Dirección General de Culturas Populares e Indígenas. pp: 83- 122. Astorga, Luis. 2012. El siglo de las drogas. El narcotráfico, del porfiriato al Nuevo Milenio. México. Editorial GrijalboProceso.

BASETEC. 1999. Base de datos de tecnología agropecuaria del Estado de Tlaxcala. México. CD del INIFAP y Fundación Produce Tlaxcala.

Boege, Eckart. 2008. El patrimonio biocultural de los pueblos indígenas de México. Hacia la conservación in situ de la biodiversidad y la agrodiversidad de los territorios indígenas. México. INAH, CONACULTA, CDI.

Brush, Stephen, and Hugo Perales. 2007. A maize landscape: Ethnicity and agro-biodiversity in Chiapas Mexico. Agriculture,Ecosystems \& Environment. Vol.121, Núm.3. pp: 211-221.

Carpenter, Jhon. 2007. Etnohistoria de la tierra caliente. Los grupos indígenas de Sinaloa al momento del contacto español. México. La crónica de Sinaloa-COBAES-Difocur.

Carrillo, Arturo. 2013. Agua, agricultura y agroindustria. Sinaloa en el siglo XX. México. Universidad Autónoma de SinaloaUniversidad Autónoma de Nuevo Léon.

Casas, Alejandro, Alfonso Valiente-Banuet, Edgar Pérez-Negrón, y Leonor Solís. 2010. El manejo de la biodiversidad en el desierto: el valle de Tehuacán-Cuicatlán. In: Víctor M. Toledo (coord). La biodiversidad de México. Inventarios, manejo, usos, informática, conservación e importancia cultural. México. FCE-CONACULTA. pp: 235-272. 
Colín, Jesús Sales, Ma Guadalupe Robles, y Tomás Martínez. 2015. Agricultura guarijía en la cuenca media del río Mayo, Álamos, Sonora. Geografía Agrícola, estudios regionales de la agricultura mexicana. Vol. 34 Núm 54. pp: 9-24.

Cortés-Gregorio, I, Erika Pascual-Ramos, Salvador M. Medina, Eduardo Sandoval, Estuardo Lara, Hugo Piña, Rosa Martínez, y Gustavo Rojo. 2013. Etnozoología del pueblo mayoyoreme en el norte de Sinaloa: uso de vertebrados silvestres. Agricultura, Sociedad y Desarrollo. Vol.10, Núm.3. pp: 335-358.

Chauvet, Michelle, y Elena Lazos. 2014. El maíz transgénico en Sinaloa: ¿tecnología inapropiada, obsoleta o de vanguardia? Implicaciones socioeconómicas de la posible siembra comercial. Sociológica, Año 29, Núm. 82. pp: 7-44.

Espinosa de la Mora, Dulce. 2005. Entre más, mas: La conservación de maíces locales en las comunidades de Baymena y Guadalupe en Choix, Sinaloa. Tesis de Licenciatura. México. INAH-SEP

Fernández, Rocío, Luis Morales, y Amanda Gálvez. 2013. Importancia de los Maíces Nativos de México en la dieta nacional. Una Revisión Indispensable. Revista Fitotecnia Mexicana, Vol. 36, Núm. 3-A. pp: 275-283.

González, Mónica, Natalia Palacios, Armando Espinoza, y Claudia Bedoya. 2013. Diversidad Genética en maíces Nativos Mexicanos Tropicales. Revista Fitotecnia Mexicana, Vol. 36, Núm. 3-A, octubre. pp: 329-338.

Goodman, Major, Walton Galinat. 1988. The history and evolution of Maize. Critical Reviews in Plant Sciences, Vol. 7, No. 3. pp: 197-220.

Hewit de Alcántara, Cynthia. 1978. La modernización de la agricultura mexicana 1940-1970. México, Siglo XXI.

INEGI. 2009. EL Fuerte, Sinaloa. Prontuario de información geográfica municipal de los Estados Unidos Mexicanos. Clave geoestadística 25010. México. Instituto Nacional de Estadística, Geografía e Informática.

INEGI. 2010. Censo de Población y Vivienda 2010. Principales resultados por localidad (ITER). México. Instituto Nacional de Estadística, Geografía e Informática. Disponible en: http://www3.inegi.org.mx/sistemas/TabuladosBasicos/Default.aspx? $\mathrm{c}=27302 \&$ s $=$ est

Flores, Hilario, Waldo Ojeda, y Ernesto Sifuentes. 2006. Estudio retrospectivo de la sequía en el norte de Sinaloa. Multiciencia. Ciencias Naturales e Ingeniería, Vol. 1, Núm.3. Disponible en: https://www.researchgate.net/publication/270396578_ ESTUDIO_RETROSPECTIVO_DE_LA_SEQUIA_EN_ EL_NORTE_DE_SINALOA.pp: 15-20.

Lara, Estuardo, Mario Aliphat, y Benito Ramírez. 2002. Zentli: la agricultura del maíz en una comunidad nahua de la Malinche, Tlaxcala. México. Colegio de Postrgaduados-Instituto
Tlaxcalteca de la Cultura-Unidad de Culturas Populares e Indígenas de Tlaxcala.

Lara, Estuardo, Mario Aliphat, y Benito Ramírez. 2005. El conocimiento campesino náhuatl en el agroecosistema tradicional de maíz (Zea mays L.): Estudio de caso en San Isidro Buen Suceso, Tlaxcala. Comunicaciones en Socioeconomía, Estadística e Informática. Vol. 9, Núm. 2. pp: 25-44.

Lara, Estuardo, Laura Caso, y Mario Aliphat. 2012. El sistema milpa roza, tumba, quema de los Maya Itzá de San Andrés y San José, Petén, Guatemala. Ra Ximhai. Vol. 8, Núm. 2. pp: 71-92.

Lazos, Elena. 2008. La invención de los transgénicos: ¿nuevas relaciones entre naturaleza y cultura? Nueva Antropología. Vol. XXI, Núm. 68. pp: 9-35.

López, Francisco, Ana Hilda Ramírez, y Ramón Martínez. 1996. Los mayos de Huites, desplazados por la presa. Estudios Sociales. Vol. 6, Núm. 12. pp: 245-261.

López, Hugo. 2007. Los Mayos de Sinaloa: esbozo etnográfico y regional. Cuicuilco. Vol. 14, Núm. 39. pp: 11-33.

López-Torres, Rufino, y José Vargas-Hernández. 2005. Impacto de los programas oficiales de gobierno en los últimos diez años en la comunidad de Jahuara II, El Fuerte, Sinaloa, México. Ra Ximhai. Vol. 1, Núm. 1. pp: 67-80.

Martín, José G., José Ron, José Sánchez, Lino De la Cruz, Moisés M. Morales, José A. Carrera, Alejandro Ortega, Víctor A. Vidal, y Manuel Guerrero. 2008. Caracterización agronómica y morfológica de maíces nativos del noroccidente de México. Revista Fitotecnia Mexicana, Vol. 31, Núm. 4. pp: 331-340.

Moctezuma, José Luis, y Hugo López. 2007. Mayos. Pueblos Indígenas del México Contemporáneo. México, CDI. Disponible en: http://www.cdi.gob.mx.

Moctezuma, José Luis, y Alejandro Aguilar. 2013. Los Pueblos Indígenas del Noroeste Atlas Etnográfico. México, INAH, 2013

Moreno-Calles, Ana, Víctor Toledo, y Alejando Casas. 2013. Los Sistemas Agroforestales Tradicionales de México: Una Aproximación Biocultural. Botanical Sciences Vol. 91, Núm. 4. pp: 375-398.

Ojeda-Bustamante, Waldo, Ernesto Sifuentes-Ibarra, Mauro Íniguez-Covarrubias, y Martín J. Montero-Martínez. 2011. Impacto del Cambio Climático en el Desarrollo y Requerimientos Hídricos de los Cultivos. Agrociencia Vol. 45. pp: $1-11$.

Rentería, R, y F. Mora. 2013. Economía y aprovechamiento de los recursos naturales. En Los pueblos indígenas del noroeste. In: J. Luis Moctezuma y Alejandro Aguilar ZA (coords). Atlas etnográfico. México. Instituto Sonorense de Cultura/ Instituto Nacional de Lenguas Indígenas/Instituto Nacional de Antropología e Historia. pp: 209-242. 
Romero-Higareda, César, Gilberto Márquez, Rogelio Sánchez, y Estela Fierros. 2014. Tendencias climáticas en el estado de Sinaloa. In: Miguel Flores, Enrique Morán, Carlos Karam (eds). Sinaloa ante el cambio climático global. México Universidad Autónoma de Sinaloa-INAPI. pp: 77-106.

Ruiz, José Ariel, José de J. Sánchez, Juan M. Hernández, Martha C. Willcox, Gabriela Ramírez, José L. Ramírez, y Diego R. González. 2013. Identificación de razas mexicanas de maíz adaptadas a condiciones deficientes de humedad mediante datos biogeográficos. Revista Mexicana de Ciencias Agrícolas. Vol.4 Núm.6. pp: 829-842.
Sandoval-Forero, Eduardo, y Ma. Eugenia Meza-Hernández. 2013. La interculturalidad en la etnorregión Yoreme Mayo de Sinaloa. Papeles de Población. Vol.19 Núm.77. pp: 193204.

Schwartz, Norman, and Rolando Corzo. 2015. Swidden counts: a Petén, Guatemala, milpa system Production, Carrying Capacity, and Sustainability in the Southern Maya Lowlands. Journal of Anthropological Research. Vol. 71, No. 1. pp: 69-93.

Yetman, David, and Thomas Van Devender. 2002. Mayo Ethnobotany. Land, History, and Traditional Knowledge in Northwest Mexico. London, England. University of California Press. 